\title{
PERKARA MAFQUD DI PENGADILAN AGAMA DI PROVINSI RIAU DALAM PERSPEKTIF KEADILAN GENDER
}

\author{
Sofia Hardani, Asmiwati \\ UIN Sultan Syarif Kasim Riau, Indonesia \\ sofia.hardani@uin-suska.ac.id, asmiwati@gmail.com \\ Dewi Nofrita \\ IAIN Fattahul Muluk Jayapura, Indonesia \\ dewinofritasjafri@gmail.com
}

\begin{abstract}
This paper aims to reveal how mafqud cases submitted to the Court in Rian Province, how the process of settlement of the matter, and how gender analysis against both these problems. The religious court in Riau Province, the events are referred to as occult husband mafqud, namely the departure of her husband in a long time with no known keberdaannya. Cases mafqud happens very related to personal condition and the condition of the couple's household. This includes educational level, tradition, the age of marriage, work, and relationships within the household. The process of things unseen longer on stage calling compared the matter to sue for divorce, but the hearing process is quite short due to the absence of a defendant, and terminated with verstek. In the perspective of gender, the missing husband is one form of deed tyrant and irresponsible. But it is inseparable from the personal background conditions with low levels of education, lack of knowledge of the laws of the religion, does not have a regular job, and low income. Therefore, they need to get awareness will preclude responsibility, get coaching mental and religious and decent jobs. Women who left the occult needs to get perlindungam, good social, psychic, as well as the economy.
\end{abstract}

Keywords: Divorce; Mafqud; The occult; Gender Justice

\begin{abstract}
ABSTRAK
Tulisan ini bertujuan untuk mengungkapkan bagaimana kasus-kasus mafqud yang diajukan ke Pengadilan Agama di Provinsi Riau, bagaimana proses penyelesaian perkaranya, dan bagaimana analisis gender terhadap kedua permasalahan tersebut. Di Pengadilan Agama di provinsi Riau, peristiwa mafqud disebut dengan suami ghaib, yaitu kepergian suami dalam waktu yang lama tanpa diketahui keberdaannya. Kasus-kasus mafqud yang terjadi sangat terkait dengan kondisi personal dan kondisi rumah tangga pasangan. Hal ini meliputi tingkat pendidikan, tradisi, usia perkawinan, pekerjaan, dan hubungan dalam rumah tangga. Proses perkara ghaib lebih lama pada tahap pemanggilan dibanding perkara cerai gugat, akan tetapi proses sidangnya cukup singkat karena tidak adanya pihak tergugat, dan diputus dengan verstek. Dalam perspektif gender, ghaibnya suami adalah salah satu bentuk perbuatan yang zalim dan tidak bertanggung jawab.Akan tetapi hal tersebut tidak terlepas dari kondisi latar belakang personal dengan tingkat pendidikan yang rendah, kurangnya pengetahuan akan hukum-hukum agama, tidak memiliki pekerjaan tetap, dan rendahnya
\end{abstract}


penghasilan.Oleh karenanya, mereka perlu mendapatkan penyadaran akan tanggung jawab berumah tangga, mendapatkan pembinaan mental dan keagamaan serta pekerjaan yang layak. Perempuan yang ditinggal ghaib perlu mendapatkan perlindungam, baik sosial, psikis, maupun ekonomi.

Kata Kunci: Perceraian; Mafqud; Ghaib; Keadilan Gender

\section{PENDAHULUAN}

Dalam Alquran Surat An-Nisa' ayat 21 Allah swt menyebutkan bahwa ikatan pernikahan adalah ikatan yang amat kuat (mitsaqan ghalizhan)dan karenanya setiap upaya untuk meremehkan ikatan suci ataupun memperlemahnya, apalagi memutuskannya adalah sangat dibenci oleh agama. Ibn Umar r.a meriwayatkan bahwa Nabi Saw. Pernah bersabda (Muhammad Bagir Al-Habsyi, 2002):

"Dari Ibnu Umar Radliyallaahu 'anbu babwa Rasulullah Shallallaabu 'alaibi wa Sallam bersabda: "Perbuatan halal yang paling dibenci Allab ialah cerai." (Riwayat Abu Dawud dan Ibnu Majah.).

Dalam perjalanan sebuah perkawinan, adakalanya perceraian merupakan keniscayaan yang tidak mungkin dihindarkan, karena dinamika rumah tangga manusia tidak kekal sifatnya, meskipun tujuan pernikahan adalah hendak membangun rumah tangga yang kekal dan bahagia (Mustofa Hasan, 2011). Realita kehidupan manusia membuktikan bahwa banyak hal yang dapat meruntuhkan mahligai rumah tangga sehingga sia-sia untuk untuk dipertahankan. Hal ini dapat dapat disebabkan kerena adanya ketidakseimbangan mengenai porsi pelaksanaan kewajiban dan penerimaan hak, atau adanya perbedaan watak, kepribadian, pengalaman dan intelektual masing masing suami isteri.

Salah satu permasalahan rumah tangga adalah kepergian suami meninggalkan keluarganya untuk sekian lama, menghilang tanpa diketahui beritanya dan meninggalkan kewajibannya sebagai seorang suami, sehingga menimbulkan kerugian lahir dan batin bagi isteri dan anak yang ditinggalkan. Dalam istilah fikih, kepergian suami tanpa diketahui keberadaannya tersebut disebut mafqud.

Permasalahan yang dihadapi perempuan karena mafqudnya suami dapat berbentuk tekanan psikologis karena ketiadaan suami yang mendampingi, timbulnya fitnah, apalagi jika perempuan tersebut masih muda, masalah anak-anak, dan lain sebagainya. Persoalan nafkah juga akan menimbulkan masalah tersendiri bagi perempuan yang ditinggalkan suaminya, baik nafkah lahir, maupun nafkah batin, apalagi jika istri tidak memiliki kemandirian ekonomi dan menggantungkan hidupnya kepada suami. 
Dalam kondisi suami yang mafqud tersebut, Islam memberikan jalan keluar bagi perempuan, yaitu membolehkan bercerai dari suaminya yang tidak jelas keberadaannya tersebut. Alasan kebolehan menceraikan didasarkan kepada menolak kemudaratan atau kerugian bagi istri. Pemisahan ini diqiyaskan pada kerugian yang ditimbulkan oleh ila' dan impotensi yang dialami suami. Dengan demikian, istri jugamempunyai hak khiyar untuk meminta cerai seperti pada kedua peristiwa tersebut.

Dalam aturan perkawinan di Indonesia, peristiwa mafqudnya suami dapat dijadikan salah satu alasan bagi istri untuk mengajukan perceraian ke Pengadilan Agama demi kejelasan statusnya. Hal ini disebutkan dalam pasal 19 PP No 9 Tahun 1975 huruf b atau dalam pasal $116 \mathrm{KHI}$ huruf b disebutkan bahwa perceraian dapat terjadi karena alasan, "Salah satu pihak meninggalkan pibak lain selama 2 (dua) tabun berturut-turut tampa izin pibak lain dan tanpa alasan yang sah atau karena hal lain diluar kemampuannya”.

Berdasarkan hal di atas, menarik untuk dikaji selanjutnya, apabila pertimbangan untuk penetapan mafqudnya seorang suami beserta akibatnya dikaitkan dengan prinsip keadilan gender. Apalagi jika hal ini dikaitkan dengan perkembangan teknologi komunikasi seperti zaman sekarang, dimana keberadaan seseorang tidaklah membutuhkan waktu yang lama untuk mengetahuinya. Oleh karena itu, pokok masalah dalam penelitian ini diarahkan kepada bagaimana kasus-kasus mafqud yang diajukan ke Pengadilan Agama, bagaimana proses penyelesaian perkara mafqud di Pengadilan Agama, dan bagaimana analisis gender terhadap kedua permasalahan tersebut.

\section{METODE PENELITIAN}

Penelitian ini dilakukan di Pengadilan Agama yang ada di Provinsi Riau. Karena luasnya wilayah Riau yang terdiri dari 13 Kabupaten/Kota, dan masing-masingnya memiliki Pengadilan Agama kecuali Siak Sri Indrapura, maka penulis mengambil sampel sebnayak 3 Pengadilan Agama saja, yaitu Pekanbaru, Bangkinang, dan Pelalawan, dengan pertimbangan kemudahan pengumpulan data. Data primer diperoleh langsung dari berkas-berkas perkara mafqud serta proses penyelesaian perkara mafqud yang ada di PA, dan data sekunder diperoleh melalui studi kepustakaan yang meliputi buku-buku, jurnal, artikel, hasil-hasil penelitian yang berkaitan dengan obyek penelitian. Data dikumpulkan melalui wawancara yang dilakukan terhadap para hakim dan para panitera yang melakukan persidangan perkara mafqud di Pengadilan Agama. Dari mereka diperoleh informasi-informasi tentang 
pertimbangan-pertimbangan mereka dalam menetapkan mafqud dan akibat-akibat hukum yang akan dihadapi oleh pasangan yang ditinggalkan. Data yang diperoleh dianalisa menggunakan pendekatan gender dengan teknik deskriptif kualitatif.

\section{HASIL PENELITIAN DAN PEMBAHASAN}

\section{Mafqud}

Menurut istilah Ibnu Humam al-Hanafi dalam kitab Fath al-Qadir (Juz 6), mafqūd diartikan oleh ulama Hanafiah sebagai “orang yang tidak diketahui hidup dan matinya. Ulama Malikiyah Abu Bakar bin Hasan al-Kasynawi dalam kitab Ashäl al-Madārike (Juz 1) menjelaskan bahwa mafqud ialah orang yang hilang dari keluarganya dan mereka merasa kehilangan orang tersebut hingga terputus kabar mengenai orang yang hilang tersebut". Menurut Wahbah az-Zuhaili dalam Al-Fikih al-Islämiy wa 'Adillatubu, (Juz 9) mafqūd ialah orang hilang yang tidak diketahui apakah masih hidup yaitu bisa diharapkan kehadirannya ataukah sudah mati berada dalam kubur. Dari beberapa definisi terebut dapat dipahami bahwa mafqüd adalah hilangnya seseorang dari suatu tempat, tidak diketahui kabar dan keberadaannya secara pasti, serta tidak diketahui apakah masih hidup atau sudah meninggal dunia. Para ulama berbeda pendapat tentang status istri yang suaminya mafqud .Ulama Hanafiyah dan Syafi'iyah mengatakan bahwa seorang istri yang ditinggal lama oleh suaminya hendaknya sabar dan tidak boleh menuntut cerai, karena pada asalnya pernikahan antara keduanya masih berlangsung sehingga terdapat keterangan yang jelas bahwa suaminya meninggal atau telah menceraikannya. Kelompok ini cenderung memandangnya dari segi positif, yaitu dengan menganggap orang yang hilang itu masih hidup sampai dapat dibuktikan jika ia telah wafat. Pendapat ini berdasarkan kaidah istishab, yaitu menetapkan hukum yang berlaku sejak semula sampai ada dalil yang menunjukan hukum lain. Alasan lain pendapat ini adalah hadis yang diriwayatkanoleh Suwar ibn Mas'ab dari Muhammad bin Syurahbil al-Hamdani, dari Mughirah bin Syu'bah berkata, Rasulullah saw. bersabda,"istri orang yang hilang tetap sebagai istrinya sampai ia mendapat berita (tentang kematiannya).”(HR. ad-Dār Quthnî).

\section{Mafqūd dalam Hukum Positif di Indonesia}

Dalam hukum positif di Indonesia disebutkan bahwa seorang istri akan tetap menjadi istri dari suami yang menikahinya secara sah sampai suaminya menceraikannya, atau dia sendiri yang mengajukan cerai dan pengajuannya itu diterima oleh pihak 
berwenang, yakni Pengadilan Agama. Istri berhakmengajukan cerai yang disebut khulu', tetapi itu terlebih dahulu harus diputuskan olehPengadilan Agama. Bila tidak mengajukan khulu' atau tuntutan apapun, maka istri yang ditinggal mafqüd suaminya dianggap ridha terhadap perlakuan suami yang menghilang. Apabila sejak awal akad nikah sudah ada sighat thalaq ta'liq dimana salah satu poinnya adalah, "jika suami menghilang dalam jangka waktu tertentu (harus disebutkan beberapa lama), atau tidak memberi nafkah, atau hal lain maka otomatis akan jatub talak,", barulah si istri yang ditinggal (mafqüd) bisa dikatakan bercerai secara otomatis.

Dalam Kitab Undang-Undang Hukum Perdata (KUHPer) telah tercantum ketentuan mengenai mafqud (orang hilang). KUHPer tidakmenggunakan istilah mafqud, akan tetapi menggunakan istilah "orang yangdiperkirakan telah meninggal dunia”.Dalam Pasal 467, KUHPer menentukan bahwa seseorang yang telahpergi meninggalkan tempat kediamannya dalam jangka waktu 5 tahun, atautelah lewat waktu 5 tahun sejak terakhir didapat berita kejelasan tentangkeadaan orang tersebut, tanpa memberi kuasa untuk mewakili urusanurusandan kepentingan-kepentingannya, dapat dimohonkan oleh pihak yangmemiliki kepentingan keperdataan dengan orang tersebut ke pengadilan untukdipanggil menghadap ke persidangan untuk memastikan keberadaan dan nasibnya.*

\section{Gender}

\section{a. Pengertian Gender}

Untuk memahami konsep gender, maka harus dapat dibedakan antara kata gender dengan seks (jenis kelamin). Pengertian seks (jenis kelamin) merupakan pembagian dua jenis kelamin (penyifatan) manusia yang ditentukan secara biologis yang melekat pada jenis kelamin tertentu, dan tidak dapat berubah dan merupakan ketentuan biologis atau sering dikatakan sebagai kodrat (kehendak Tuhan). Istilah gender pertama kali diperkenalkan oleh Robert Stoler (1968) untuk memisahkan pencirian manusia yang didasarkan pada pendefinisian yang bersifat sosial budaya dengan pendefinisian yang berasal dari ciri-ciri fisik biologis. Selain Stoller, Oakley dalam Kementerian Negara Pemberdayaan Perempuan RI dan Women Support Project II/CIDA (2001) mengartikan gender

*Jangka waktu panggilan ini adalah dalam waktu 3 bulan. Jika orang tersebut tidak dapat menghadap untuk memberikan kesan dan petunjuk bahwa dia masih hidup, walaupun telah dipanggil untuk yang kedua kalinya, begitu seterusnya sampai panggilan ketiga dengan jangka waktu panggilan selama 3 bulan. Panggilan tersebut diumumkan di surat-suratkabar, papan pengumuman di pengadilan, dan papan pengumuman di alamatterakhir orang tersebut diketahui.R. Subekti dan Tjitrosudibio, Kitab Undang Undang Hukum Perdata, (Jakarta: PT Pradnya Paramita, 1995), hal. 144. 
sebagai konstruksi sosial atau atribut yang dikenakan pada manusia yang dibangun oleh kebudayaan manusia.

\section{b. Konsep Kesetaraan Gender dalam Islam}

Alquran memberikan pandangan optimistis terhadap kedudukan dan keberadaan perempuan. Semua ayat yang membicarakan tentang Adam dan pasangannya, sampai keluar ke bumi, selalu menekankan kedua belah pihak dengan menggunakan kata ganti untuk dua orang (dlamir mutsanna), seperti kata buma, misalnya keduanya memanfaatkan fasilitas sorga. Dalam surat Al-Baqarah ayat 35 Allah SWT berfirman:

" dan Kami berfirman: "Hai Adam, diamilah oleh kamu dan isterimu surga ini, dan makanlah makanan-makanannya yang banyak lagi baik dimana saja yang kamu sukai, dan janganlah kamu dekati pohon ini, yang menyebabkan kamu Termasuk orang-orang yang zalim.” (Q.S, 2:35)

\section{Kasus Mafqud di Pengadilan Agama di Provinsi Riau}

Istilah mafqud, ditemukan di dalam pasal 71 (b) Kompilasi Hukum Islam. Di dalam ketentuan fikih, sebagaimana sudah dikemukakan sebelumnya, peristiwa ini dapat dijadikan alasan bagi istri untuk melakukan gugat cerai ke Pengadilan Agama. Akan tetapi, setelah melakukan penelitian, peristiwa menghilangnya suami yang tidak diketahui lagi beradaannya dikategorikan kepada peristiwa "ghaib" oleh Pengadilan Agama, bukan mafqud. Artinya, konsep mafqud sebagaimana dijelaskan di dalam kitab-kitab fikih klasik tidak ditemukan pada perkara-perkara yang diajukan ke Pengadilan Agama, meskipun peristiwa tersebut berkemungkinan terjadi pada zaman sekarang, umpamanya suami mengalami kecelakaan akan tetapi tidak diketahui apakah dia masih hidup atau sudah meninggal (wawancara : Usman KPA Dumai, 2017). Kasus yang ada hanyalah seumpama: suami pergi mencari pekerjaan ke luar kota dan tidak ada kabar berita setelah kepergiannya dan tidak diketahui keberadaannya. Atau bisa juga terjadi pihak istrilah yang pergi meninggalkan rumah dan tidak diketahui keberadaannya setelah sekian lama. Ghaibnya suami, ataupun istri bisa dijadikan alasan untuk mengajukan perceraian dan jumlah kasus ghaib ini cukup banyak di Pengadilan Agama Pekanbaru dan Pengadilan Agama Dumai. Di Pengadilan Agama Pekanbaru, dari 100 \% kasus Cerai Gugat yang masuk setiap bulannya, sekitar 20\% nya merupakan Cerai Gugat karena ghaibnya suami (wawancara : Nursyamsiah Hakim PA Pekanbaru, 2017). Demikian juga di Pengadilan Agama Dumai, sebanyak rata-rata 60 perkara yang masuk setiap bulannya, 15 perkara merupakan perkara ghaibnya pasangan (wawancara : Hasan Nulhakim Hakim PA Dumai, 2017). 
Untuk mengidentifikasi kasus "ghaib" di Pengadilan Agama perlu mempelajari semua dokumen gugatan perceraian yang diputuskan oleh Pengadilan Agama, karena Pengadilan Agama tidak memilah kasus mafqud/ghaib menjadi satu jenis perkara tersendiri. Kategori penyelesaian keluarga bermasalah di Pengadilan Agama hanyalah Cerai Talak (CT) dan Cerai Gugat (CG). Kasus 'ghaib” termasuk kepada bagian dari kasus Cerai Gugat yang disampaikan oleh pihak isteri terhadap suaminya, dan kasus ghaib yang dimaksudkan dalam penelitian ini diarahkan kepada perkara Cerai Gugat yang diajukan perempuan yang ditinggalkan oleh suaminya lebih dari dua tahun bertutut-turut tanpa ada kabar berita yang diterima.

Oleh karena banyaknya kasus Cerai Gugat yang diajukan ke pengadilan Agama, sejak Januari sampai bulan Oktober 2017 tercatat sebanyak 1.462 kasus yang terdiri dari 983 perkara Cerai Gugat dan 348 kasus cerai talak, sedangkan kasus ghaib tidak diketahui jumlahnya secara pasti, maka penulis mengambil sampel secara purposive sebanyak 20 kasus.

Dari 20 kasus yang diteliti, dapat diketahui tentang segala sesuatu yang berhubungan dengan perkara ghaib tersebut, khususnya yang terkait dengan pokok masalah, yaitu penyelesaian perkara mafqud di Pengadilan Agama dan kondisi keluarga yang ditinggalkan oleh suami yang ghaib.

Mengamati berkas perkara CG yang diajukan ke PA, dapat diketahui kondisi personal maupun kondisi rumah tangga pasangan yang dijadikan sampel tersebut sebelum suami meninggalkan rumah, baik itu pendidikan, usia perkawinan, pekerjaan, dan hubungan dalam rumah tangga. Keadaan tersebut dapat dilihat pada tabel-tabel di bawah ini.

Tabel 1 Pendidikan pasangan dalam kasus ghaib

\begin{tabular}{|c|c|c|c|c|c|c|}
\hline No & $\begin{array}{c}\text { Pendidikan } \\
\text { Suami }\end{array}$ & Jumlah & $\%$ & $\begin{array}{c}\text { Pendidikan } \\
\text { Istri }\end{array}$ & Jumlah & $\%$ \\
\hline 1 & SD & 2 & 10 & SD & 2 & 10 \\
\hline 2 & SLTP & 1 & 5 & SLTP & 1 & 0 \\
\hline 3 & SLTA & 15 & 75 & SLTA & 14 & 70 \\
\hline 4 & S1 & 2 & 10 & S1 & 3 & 15 \\
\hline & Jumlah & 20 & 100 & Jumlah & 20 & 100 \\
\hline
\end{tabular}

Tabel 1 menunjukkan bahwa tingkat pendidikan pasangan pada kasus mafqud berimbang. Tidak ada perbedaan yang mencolok antara pendidikan istri dan pendidikan suami. Mayoritas pendidikan suami adalah SLTA (75\%), demikian juga istri. Akan tetapi di antara pasangan tersebut ada rumah tangga yang pendidikan istri lebih tinggi dari pendidikan suami. 
Tabel 2 Pekerjaan suami yang ghaib

\begin{tabular}{|c|l|c|c|}
\hline No. & \multicolumn{1}{|c|}{ Pekerjaan } & Jumlah & $\%$ \\
\hline 1 & Sopir & 5 & 25 \\
\hline 2 & Karyawan swasta & 3 & 15 \\
\hline 3 & Wiraswasta & 12 & 60 \\
\hline 4 & Tani Jumlah $=$ & 1 & 5 \\
\hline & 20 & $100 \%$ \\
\hline
\end{tabular}

Dari tabel 2 dapat diketahui bahwa pekerjaan suami yang ghaib mayoritas adalah wiraswasta (60\%), kemudian sopir (25\%), karyawan swasta (15\%) dan tani (5\%). Dengan demikian dapat dipahami bahwa suami tidak terlalu terikat dengan pekerjaannya, sehingga mereka bisa pergi mencari pekerjaan yang lain jika mereka mau.

Lamanya suami ghaib cukup bervariasi, ada yang enam bulan tanpa kabar berita, tetapi ada yang lebih sepuluh tahun (wawancara : Nursyamsiah Hakim PA Pekanbaru, 2017). Dari 20 kasus yang dijadikan sampel pada penelitian ini, lamanya suami ghaib dapat dilihat pada table 3:

Tabel 3 Lamanya suami ghaib

\begin{tabular}{|c|c|c|c|}
\hline No. & Lamanya ghaib & jumlah & Persentase \\
\hline 1 & $2 \mathrm{~s} / \mathrm{d} 4$ tahun & 7 & $35 \%$ \\
\hline 2 & $4 \mathrm{~s} / \mathrm{d} 8$ tahun & 8 & $40 \%$ \\
\hline 3 & 8 tahun lebih & 5 & $25 \%$ \\
\hline & Jumlah & 20 & 100 \\
\hline
\end{tabular}

Tabel di atas menunjukkan bahwa perempuan yang mengajukan gugat cerai ke PA paling banyak sudah ditinggalkan suami selama 4 s/d 8 tahun, yaitu $40 \%$, sementara $35 \%$ dari kasus adalah ghaibnya suami selama 2 s/d 4 tahun, dan $25 \%$ kasus yang dijadikan sampel merupakan kasus ghaib selama 8 tahun lebih.

Sebelum suami pergi meninggalkan rumah, berdasarkan alasan gugatan yang diajukan oleh istri ke PA, kondisi rumah tangga mereka dapat di lihat pada table berikut:

Tabel 4 Kondisi rumah tangga sebelum suami ghaib

\begin{tabular}{|c|c|c|c|}
\hline No & Kondisi hubungan & Jumlah & $\%$ \\
\hline 1 & Bertengkar & 13 & 65 \\
\hline 2 & Tidak bertengkar & 7 & 35 \\
\hline & Jumlah & 20 & $100 \%$ \\
\hline
\end{tabular}

Dari tabel 4 diketahui bahwa pada umumnya, suami pergi dari rumah dan menghilang (ghaib) karena sebelumnya rumah tangga mereka tidak harmonis karena adanya pertengkaran $(65 \%)$. Sebagian menyatakan bahwa tidak ada pertengkaran sebelum suami meninggalkan rumah (35\%). Meskipun demikian, menurut Pengadilan Agama Pekanbaru 
ada pertengkaran atau tidak, ditinggalkan dalam waktu yang lama tanpa kabar berita dan nafkah sudah membuat mereka menderita.

Demikian gambaran rumah tangga pada kasus-kasus cerai gugat disebabkan ghaibnya suami. Yang pasti adalah bahwa menghilangnya suami tidak bisa diketahui penyebab yang sesungguhnya, sebagaimana juga tidak diketahui keberadaannya, apakah masih hidup ataukah sudah meninggal.

\section{Penyelesaian Perkara Mafqud/Ghaib di Pengadilan Agama}

Sebelum mengajukan perkara "ghaib" ke Pengadilan Agama, pemohon terlebih dahulu harus meminta surat keterangan kepada pejabat yang berwenang di daerah domisilinya, yaitu Ketua RT, RW, dan Lurah, tentang ghaibnya si termohon. Surat keterangan itulah yang dijadikan alasan oleh Pengadilan Agama untuk menyatakan perkara tersebut sebagai perkara gugatan dengan alasan ghaib (wawancara : Hasan Nulhakim Hakim PA Dumai, 2017).

Di dalam pasal 66 Undang-Undang No.7 tahun 1989 tentang Peradilan Agama dijelaskan tentang tempat pengajuan gugatan perceraian. Untuk perkara Cerai Talak (CT) gugatan diajukan di tempat berdomisilinya tergugat. Oleh karena yang mengajukan gugatan talak adalah pihak laki-laki, maka berarti gugatan diajukan ke Pengadilan Agama tempat berdomisilinya pihak perempuan jika mereka sudah berpisah tempat tinggal. Jika pihak perempuan bedomisili di Luar Negeri, maka gugatan CT diajukan di tempat berdomisilinya si penggugat (pihak laki-laki), dan jika kedua belah pihak berdomisili di luar negeri, maka gugatan diajukan ke Pengadilan Agama di wilayah hukum perkawinan dilangsungkan atau di Pengadilan Agama Jakarta Pusat.

Berbeda dengan perkara Cerai Gugat (CG) menurut pasal 73 UU No. 7 tahun 1989 tentang Peradilan Agama, pengajuannya dilakukan oleh istri sebagai penggugat di wilayah hukum tempat berdomisilinya, bukan tempat berdomisilinya suami. Oleh karena ghaib termasuk kedalam kategori cerai ini, maka gugatan cerai karena hilangnya suami tersebut diajukan di wilayah hukum pengadilan Agama tempat tinggal istri. Jika istri berdomisili di luar negeri, maka gugatan diajukan di daerah hukum peradilan tempat perkawinan mereka dilangsungkan atau ke Pengadilan Agama Jakarta Pusat.

Pada umumnya, dalam menyelesaikan perkara Cerai Gugat (CG) di Pengadilan Agama, pihak pengadilan tidak mengambil waktu yang lama untuk memutuskannya, berbeda dengan penyelesaian kasus Cerai Talak (CT). Perkara CG bisa diputuskan dalam 
waktu satu bulan, sementara perkara CT bisa lebih lama (wawancara : Mursyidah Panitera Hukum Muda PA Pekanbaru, 2017).

Cepatnya proses penyelesaian CG di Pengadilan Agama biasanya adalah disebabkan perkara tersebut diputuskan secara verstek, yaitu suatu putusan yang ditetapkan tanpa kehadiran pihak tergugat. Dalam hukum beracara mengenai verstek telah diatur dalam pasal 125-129 HIR dan pasal 149- 153 RBg. Dalam peraturan putusan verstek diartikan putusan yang dijatuhkan oleh majelis hakim tanpa hadirnya tergugat, ketidakhadirannya itu tanpa alasan yang sah meskipun telah dipanggil secara resmi dan patut/default without reason (Abdul Manan, 2006).

Dalam prosesnya, setelah CG diajukan oleh penggugat, pihak pengadilan melakukan pemberitahuan tentang adanya gugatan tersebut dengan membuat pengumuman di papan pengumuman yang ada di Pengadilan Agama dan melalui media masa, baik surat kabar maupun radio (R. Subekti dan Tjitrosudibio, 1995). Pengumuman dilakukan selama empat bulan untuk menerima informasi-informasi baru terkait dengan gugatan tersebut. Di samping itu, pengumuman juga dimaksudkan agar orang-orang yang mengetahui informasi tentang gugatan tersebut menyampaikan informasi tersebut kepada pihak tergugat, apakah melalui saudara, keluarga, maupun orang-orang yang mengenalnya.

Setelah pengumuman dilakukan selama empat bulan, maka dilakukan proses persidangan. Apabila dalam sidang pertama Penggugat hadir sedang Tergugat tidak hadir, maka Hakim dapat: (a) Menunda persidangan untuk memanggil Tergugat sekali lagi; atau (b) Menjatuhkan putusan verstek, karena dipanggil lagi untuk kedua kalinya atau lebih dan tetap tidak hadir maka dapat dijatuhkan putusan verstek (H. A. Mukti Arto, 1996). Putusan verstek dapat dijatuhkan apabila: (a) Tergugat telah dipanggil dengan patut dan resmi; (b) Tergugat tidak hadir dalam sidang dan tidak menyuruh orang lain untuk hadir sebagai wakilnya serta tidak ternyata bahwa ketidak hadirannya itu disebabkan oleh sesuatu halangan/alasan yang sah; (c) Penggugat hadir dalam sidang dan mohon putusan.

Dari keterangan di atas jelas bahwa persidangan yang tidak dihadiri oleh tergugat diputuskan secara verstek. Keputusan inilah yang berlaku dan biasanya digunakan untuk penyelesaian kasus mafqud di Pengadilan Agama.

Dalam proses perkara ghaib, atau menghilangnya suami dalam waktu yang lama, biasanya hakim terlebih dahulu memeriksa dokumen yang membuktikan ke"ghaib"an suami yang ditandatangani oleh pejabat yang berwenang. Kemudian, di dalam persidangan, hakim menyarankan kepada pihak istri untuk bersabar dan menunggu kepulangan suaminya 
(salinan putusan perkara nomor Nomor 0932/Pdt.G/2013/PA.Pbr). Apabila istri sudah bertekad untuk menuntut haknya, karena sudah ditinggalkan sekian lama tanpa ada kabar berita, maka hakim melanjutkan proses perkara dengan mendengarkan keterangan para saksi. Jika bukti-bukti keghaiban suami sudah diyakini oleh hakim, dan setelah memberikan nasihat-nasihat yang diperlukan, melakukan pertimbangan baik hukum positif yang berlaku di Indonesia maupun dalil-dalil syar'I, maka hakim akan memutuskan perkara tersebut secara verstek. Dengan demikian, proses perkara ghaib cukup singkat waktunya, akan tetapi proses pengumumannya memakan waktu yang panjang.

Pada kasus CT, proses yang sama juga dilakukan. Akan tetapi waktu yang digunakan untuk pengumuman gelar perkara cukup singkat, yaitu paling lama satu bulan. Dalam proses berperkara, hakim biasanya melakukan proses mediasi terlebih dahulu pada setiap perkara, baik perkara CT maupun perkara CG. Pada kasus CT, pengadilan biasanya memberikan waktu kepada pihak suami untuk berpikir kembali, setelah inkrah (penetapan) talak selama waktu enam bulan, apakah dalam waktu enam bulan tersebut suaminya tetap mentalak istrinya atau tidak. Menurut Pasal 66 UU No. 7 tahun 1989 tentang UUPA, PP No. 9 tahun tahun 1975 tentang Kekuasaan Peradilan Agama jika sudah lewat waktu enam bulan suami tidak datang maka suami tidak bisa menceraikan istrinya, kecuali dengan pengajuan baru dan alasan perceraian yang baru.

Dari keterangan di atas dapat dipahami bahwa dalam perspektif gender, penanganan kasus ghaib di Pengadilan agama menganut prinsip perlindungan terhadap perempuan. Dengan kata lain, aturan peradilan untuk penanganan kasus ghaib cukup melindungi hakhak perempuan. Hal ini dapat dilihat pada dua aspek; yaitu aspek wilayah hukum diajukannya perkara, dan kedua adalah proses keputusan yang dilakukan pengadilan yang cukup cepat dibandingkan dengan proses putusan dalam perkara Gugat Cerai karena alasan lain, ataupun proses putusan Cerai Talak.

\section{Analisis Gender terhadap Kasus Ghaib}

Untuk menganalisis kasus cerai gugat karena suami ghaib dalam perspektif gender, perlu disimak kembali tentang situasi, kondisi, maupun alasan-alasan untuk menetapkan ghaibnya suami, agar analisis yang dilakukan tidak bias gender

Dari kasus-kasus yang sudah dikemukan di atas, dapat diketahui kondisi rumah tangga dan kondisi personal pasangan suami-istri yang mengalami masalah dalam perkawinan mereka sehingga menyebabkan suami pergi meninggalkan istrinya tanpa kabar 
berita, sehingga dinyatakan ghaib oleh Pengadilan Agama.Kondisi personal yang dominan yang dapat menjadi pemicu cerai gugat karena ghaibnya suami pada kasus-kasus yang dijadikan sampel adalah tingkat pendidikan pasangan. Mayoritas mereka berpendidikan setingkat SLTA, bahkan terdapat sebagian suami hanya berpendidikan SD. Hal ini sedikit banyaknya akan berpengaruh kepada pola pikir mereka dan cara pandang mereka terhadap sebuah hubungan perkawinan. Apalagi dengan teknologi komunikasi yang semakin canggih, yang dapat membuat mereka "silau" dengan dunia maya. Ditambah lagi dengan kurangnya pendidikan agama yang diperoleh. Rendahnya tingkat pendidikan, apalagi tanpa dibarengi dengan suatu keahlian tertentu, jika dihadapkan pada kehidupan sosial yang begitu kompleks pada masa sekarang ini, terutama di bidang ekonomi, tentulah akan membuat mereka tidak mampu bersaing dengan orang-orang yang mempunyai pendidikan yang lebih tinggi dan mempunyai skill atau kemampuan tertentu pada bidangnya. Demikian pula dengan kondisi pekerjaansuami yang kurang menguntungkan, mengharuskan mereka berjuang mendapatkan pekerjaan yang lebih layak, bahkan harus meninggalkan keluarga.

Lebih jauh lagi, jika dilakukan analisis gender terhadap kasus-kasus di atas, yang menyorot sisi keadilan bagi kedua belah pihak, dapat diperhatikan hal-hal sebagai berikut:

\section{a. Pada Pihak Istri}

Seorang suami yang menyadari fungsinya sebagai qawwam tidak akan menghilang dan melepas tanggung jawabnya tanpa ada penyelesaian perkara rumah tangganya secara jelas. Seandainya yang bersangkutan meninggal dunia, tentulah diketahui, paling tidak oleh sanak saudaranya. Oleh karena itu, ghaibnya suami dapat dikatakan sebagai prilaku tidak bertanggung jawab dan melakukan kezaliman terhadap perempuan dan anak-anak yang ditinggalkan. Prilaku tersebut juga mengingkari tanggung jawab yang dipikulkan Allah SWT kepada para suami tersebut, sesuai dengan firman-Nya:

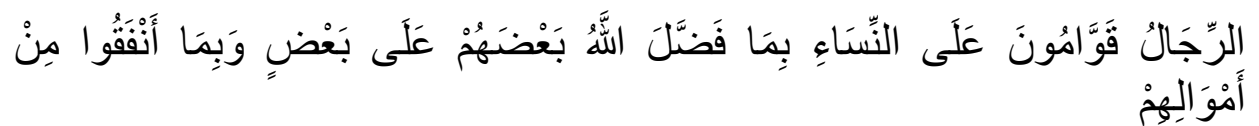

"Kaum laki-laki itu adalah pemimpin bagi kaum wanita, oleb karena Allab telah melebibkan sebahagian mereka (laki-laki) atas sebahagian yang lain (wanita), dan karena mereka (lakilaki) telah menafkahkean sebagian dari harta mereka.." (QS. An-Nisa':34)

Berdasarkan ayat Alquran di atas, seandainya sebelum ghaibnya suami, terjadi permasalahan di dalam keluarga disebabkan prilaku istri yang tidak baik, mestinya suamipun dapat mengatasi masalah tersebut secara bertanggung jawab dengan cara mendidik dan mengajari istri dengan berbagai cara yang dibenarkan. 
Seandainya suami kecewa dengan prilaku istri, atau merasa ditipu di dalam perkawinan mereka, jalan keluar yang baik tetaplah melalui penyelesaian yang jelas. Kasus-kasus ghaibnya suami sebagaimana yang dikemukakan, jelas membuat istri yang ditinggalkannya mengalami penderitaan, baik secara ekonomi maupun batiniah.* Oleh karena itu, tidaklah salah jika istri mengajukan gugatan perceraian untuk menjelaskan status perkawinannya. Karena kehidupan akan terus berjalan sementara kebutuhan fisik dan psikhis, serta ekonomi perempuan juga perlu dipenuhi.

Pada zaman sekarang, ghaibnya suami tanpa diketahui keberadaannya adalah suatu hal yang mustahil jika para suami tersebut masih mengakui statusnya sebagai suami dan kepala keluarga, mengingat perkembangan teknologi komunikasi yang semakin maju dan canggih dan dapat menjangkau berbagai pelosok negeri. Oleh karena itu, perbuatan menghilang dari keluarga dapat dikategorikan kepada perbuatan zalim dan tidak bertanggung jawab.

\section{b. Pada Pihak Suami}

Kasus menghilangnya suami tanpa diketahui keberadaannya, yang bisa saja ditetapkan oleh Pengadilan sebagai "mati hukmiy" (yang bersangkutan dianggap mati secara hukum) sehingga dengan demikian status perkawinannya bisa diceraikan, jika dilihat dari sisi suami ada beberapa hal yang perlu diperhatikan: (a) Suami boleh jadi menghadapi hal yang sulit untuk diselesaikan di dalam rumah tangganya yang menyebabkan dia sulit untuk mencari jalan keluarnya. Keadaan ini mungkin terjadi karena perselingkuhan istri yang sangat menyakitkan hatinya, atau karena prilaku istri yang tidak menghormatinya atau tidak bisa diatasinya, dan lain sebagainya. (b) Sikap mental suami yang kurang baik. Hal ini dapat disebabkan karena kurang baiknya pendidikan dari orang tua sejak masa kanak-kanak. Selain itu, rendahnya pendidikan yang dilaluinya, baik pendidikan formal maupun pendidikan non formal, baik pendidikan umum maupun pendidikan keagamaan, juga akan mempengaruhi sikap mental mereka. Sikap mental ini juga bisa diakibatkan karena factor pekerjaan yang ditekuninya yang bisa jadi tidak bisa memenuhi kebutuhan keluarga,sementara istri menuntut belanja yang lebih dari kemampuannya, dan hal ini menjadi beban yang berat bagi suami. Atau, boleh jadi malahan sebaliknya,

* Hal ini tertuang pada alasan pengajuan cerai gugat pada setiap berkas perkara cerai gugat karena suami ghaib di Pengadilan Agama. 
suami memperoleh rezeki yang berlebih sehingga dengan mudahnya ia bisa pergi mencari kehidupan yang lain. (c) Suami tidak memiliki pekerjaan yang tetap, sehingga dia tidak terikat pada disiplin dan aturan-aturan kepegawaian. Hal ini membuat mereka bisa berpindah dari suatu pekerjaan ke pekerjaan lainnya, dari satu kota ke kota lainnya, sampai mereka mendapatkan pekerjaan yang menurut mereka layak.

Terhadap kondisi-kondisi tersebut, maka pihak laki-laki perlu mendapatkan pendampingan secara tepat agar mereka bisa menyelesaikan masalahnya sesuai dengan rasa keadilan, dan tentunya sesuai pula dengan tuntunan agama.

Sebagai upaya preventif, anak laki-laki perlu mendapatkan pendidikan dan asuhan yang dapat mengasah rasa tanggung jawab yang memang seharusnya mereka pikul. Kaum laki-laki perlu mendapatkan pendidikan dan pengasahan potensi untuk dapat melakukan pekerjaan yang bisa mencukupi kebutuhan ekonomi keluarga. Mereka perlu mendapatkan advokasi untuk meningkatkan kualitas qawwam mereka sebagaimana yang disebutkan Allah dalam surat an-Nisa ayat 34.

Yang melakukan pendidikan dan advokasi tersebut tidak hanya tanggung jawab orang tua dan keluarga, tetapi juga tanggung jawab para pendidik di lembaga pendidikan formal maupun para ulama ataupun pendidik keagamaan/rohani masyarakat.

\section{Proses Penanganan Kasus}

Memperhatikan proses penanganan perkara ghaib yang dilakukan di Pengadilan Agama, sebagaimana sudah dikemukakan, dapat dipahami bahwa dalam perspektif gender penanganan kasus ghaib di Pengadilan Agama menganut prinsip perlindungan terhadap perempuan. Hal ini dapat dilihat pada dua aspek; (a) Aspek wilayah hukum diajukannya perkara, dimana pihak perempuan dapat mengajukan gugatan kepada Pengadilan Agama di wilayah hukum tempat dia berdomisili.(b) Proses keputusan yang dilakukan Pengadilan Agama yang cukup cepat dibandingkan dengan proses putusan dalam perkara Gugat Cerai karena alasan lain, ataupun proses putusan Cerai Talak.

Hanya saja, waktu dilakukannya pengumuman atau pemanggilan melalui radio ataupun media cetak tentang akan digelarnya perkara pada kasus ghaib ini, lebih lama waktunya dibanding waktu yang disediakan untuk pengumuman/pemanggilan pada kasus cerai gugat biasa dan kasus cerai talak, karena surat pemanggilan tidak bisa diantarkan 
langsung ke alamat yang dituju.

Dalam hal pemanggilan ini, ketentuan dan aturan perkara pengadilan cukup memperhatikan kepentingan pihak laki-laki, karena memberikan waktu yang lama untuk menjawab panggilan pengadilan. Setelah waktu empat bulan tersebut, seandainya pihak lakilaki mengetahui adanya perkara gugatan, maka gugur haknya untuk mengajukan keberatan.

Dalam aspek lain, setelah perkara diputus, pihak istri akan menjalani masa idah sesuai dengan kondisinya; tiga kali quru' bagi perempuan yang haidnya teratur, 90 hari bagi perempuan yang menopause, atau bahkan satu tahun bagi perempuan yang tidak haid.* Selama menjalani masa idah, perempuan tidak boleh melangsungkan pernikahan dengan laki-laki lain, bahkan tidak boleh dipinang. Kondisi ini tentunya menambah panjangnya waktu penderitaan yang dialami oleh perempuan dikarenakan suami yang ghaib.

\section{KESIMPULAN}

Di Pengadilan Agama di provinsi Riau, kasus menghilangnya suami dari keluarga disebut dengan ghaib. Faktor penyebab menghilangnya suami tidak bisa digali dari kedua belah pihak, hanya saja menurut pihak istri, sebelum suami menghilang adakalanya hubungan suami dan istri kurang harmonis dengan adanya pertengkaran-pertengkaran. Akan tetapi sebagian istri yang ditinggalkan mengaku kondisi rumah tangganya baik-baik saja, tidak ada perselisihan sebelumnya. Pada kondisi terakhir ini, faktor penyebab tentunya ada pada pihak suami, dan ini tentu tidak bisa diidentifikasi.

Perkara cerai gugat karena suami ghaib memakan waktu yang agak lama dalam tahap pemanggilan dibanding cerai gugat biasa, karena pihak tergugat tidak diketahui alamatnya. Setelah dua kali pemanggilan $(2 \times 2$ bulan), dilakukan pemeriksaan perkara. Proses pemeriksaan perkara cukup singkat karena tidak adanya pihak tergugat, dan perceraian ditetapkan dengan verstek.

Dalam perspektif gender, ghaibnya suami adalah salah satu bentuk perbuatan yang zalim dan tidak bertanggung jawab terhadap istri. Hal tersebut semestinya tidak terjadi meskipun penyebab ghaibnya suami adalah kesalahan atau prilaku istri yang tidak baik. Istri dan anak yang ditinggalkan berhak mendapatkan perlindungan dan kepastian hukum terhadap statusnya, antara lain dengan mengajukan gugatan cerai.

\footnotetext{
* Ketentuan tentang lamanya masa idah menurut hukum positif di Indonesia dapat dilihat selengkapnya pada pasal 153 Kompilasi Hukum Islam.
} 
Ghaibnya suami selama bertahun-tahun tanpa meninggalkan nafkah dan kepastian status, tentunya membuat perempuan menderita, baik secara lahir maupun batin. Ditambah lagi dengan lamanya masa idah yang harus mereka jalani setelah keputusan pengadilan, dimana mereka tidak boleh melangsungkan pernikahan, bahkan menerima pinangan dari laki-laki lain pada masa idah tersebut.

Suami yang ghaib mengindikasikan kurangnya kesadaran akan tanggung jawab yang bisa disebabkan karena rendahnya pendidikan, kurangnya pengetahuan akan hukum-hukum agama. Faktor kecilnya penghasilan dari pekerjaan yang tidak menetap juga menjadi bagian pemicu permasalahan rumah tangga, termasuk rendahnya kemampuan untuk bersaing di dunia kerja.

Para istri yang mengajukan gugatan cerai karena suaminya ghaib mestinya tidak dianggap negative oleh masyarakat sekitarnya. Mereka perlu mendapatkan perhatian, terutama di bidang ekonomi untuk dapat melanjutkan kehidupan mereka. Para suami yang menghilang pun demikian, perlu mendapatkan penyadaran-penyadaran akan tanggung jawab berumah tangga, mendapatkan pembinaan mental dan keagamaan, serta mendapatkan pekerjaan yang layak yang bisa menghidupi keluarganya.

Yang paling penting dari semuanya adalah tindakan preventif dari berbagai pihak agar paling tidak meminimalisir kasus-kasus gugatan cerai karena ghaibnya suami.Hal ini bisa dilakukan melalui pendidikan mental dan spiritual sejak kecil sampai mereka dewasa, terutama oleh kedua orang tua di rumah serta guru-guru dan masyarakat lingkungan yang lebih luas.

\section{DAFTAR PUSTAKA}

Abdul Manan, Penerapan Hukum Acara Perdata di Lingkungan Peradilan Agama (Cet.1; Jakarta: Kencana, 2006), h. 212Abu Bakar bin Hasan al-Kasynawi, Ashāl alMadārik, Juz 1, (Bairūt: Dār al-Kutūb al-'Tlmiyah, t.th), hal. 407.

Al-Habsyi, Muhammad Bagir. 2002.Fiqih Praktis Menurut Al-quran, As-Sunnah dan Pendapat Para Ulama, Bandung

Amiruddin \& Zainal Askin, 2012. Pengantar Metode Penelitian Hukum, Jakarta: Raja Grafindo Persada

Azzam, Abdul Aziz Muhammad,\& Abdul Wahhab Sayyid Hawwas, 2009, Fikih Munakahat (khitbah, Nikah dan Talak), Jakarta: Amzah 
Damartoto. Argyo, 2005. Kebutuban Praktis dan Strategis Gender, (Surakarta: Sebelas Maret University Press

Departemen Agama RI. 1991/1992. Kompilasi Hukum Islam di Indonesia. Jakarta: Dirjen Binbaga Islam

Drake, Nicholas, dan Elizabeth Davis (ed.). 1989. The Concise Encyclopaedia of Islam, London: Stacey International

Dudung Abdurrahman. 1998. Pengantar Metodologi dan Penelitian Ilmiah, Yogyakarta: IKFA

H. A. Mukti Arto, Praktek Perkara Perdata Pada Pengadilan Agama, (Pustaka Pelajar, 1996), hal. 85 .

Ibnu Humam al-Hanafi, Fathal-Qadīr,Juz 6, (Bairūt: Dār al-Kutūb al-'Ilmiyah,t.th), hal. 133.

Ibnu Rusyd, Bidāyah al-Mujtahid wa Nihayah al-Muqtashid, hal. 514.

Kementerian Negara Pemberdayaan Perempuan RI dan Women Support Project II/CIDA.2001. Gender dan Pembangunan, Jakarta: Kementerian Negera Pemberdayaan Perempuan

Maleong, Lexy. J. 2002. Metodologi penelitian Kualitatif, Bandung: PT Remaja Rosdakarya

Muhammad Bagir Al-Habsyi, 2002, Fiqih Praktis Menurut Al-quran, As-Sunnah dan Pendapat para Ulama, Bandung, Mizan, hal.181.

Mustofa Hasan, 2011, Pengantar Hukum Keluarga, Bandung, CV Pustaka Setia

Redaksi New Merah Putih, Undang-Undang Perkawinan Nomor 1 Tahun 1974,(Yogyakarta: New Merah Putih, 2009), hal. 60.

R. Subekti dan Tjitrosudibio, Kitab Undang Undang Hukum Perdata, (Jakarta: PT Pradnya Paramita, 1995), hal. 144

Sayid Sabiq. tth. Fikih Sunnah. juz 1. Bairut: Dar al-Fikr

Schacht, Joseph. 1964. An Introduction to Islamic Law. Oxford: Oxford University Press

Sugiyono. 2010. Metode Penelitian Kuantitatif Kualitatif dan R\&D. Bandung:Alfabeta

Umar, Nasaruddin. 1999. Argumen Kesetaraan Gender Perspektif Al-Quran, Jakarta: Paramadina 
Wahbah az-Zuhaili, Al-Fikih al-Islämiy wa 'Adillatubu, Juz. 9, hal. 7187

Wantjik Saleh. 1982.Hukum Perkawinan Indonesia, Jakarta Timur: Ghalia Indonesia

Wasman \& Wadah Nuromiyah. 2011.Hukum Perkawinan Islam di Indonesia (Perbandingan Fikih dan Hukum Positif), Yogyakarta: Teras

Yahya Harahap. 1990.Kedudukan Kewenangan dan Acara Pengadilan Agama (Undang-undang Nomor 7 tabun 1989), Jakarta: PT Metropolitan Press,

Zuhdi Muhdlor, 1995, Memahami Hukum Perkawinan (Nikah, Talak, Cerai, Rujuk), Bandung: Al Bayan 